\title{
Penerapan Model Discovery Learning untuk Meningkatkan Hasil Belajar Bahasa Indonesia di Kelas VIII.D SMP N 9 Muaro Jambi Semester I Tahun Ajaran 2019/2020
}

\author{
Djoko Setijono \\ Guru Bahasa Indonesia SMP N 9 Muaro Jambi \\ Correspondence email: djokosetijono02@gmail.com
}

\begin{abstract}
Abtrak. Penelitian ini bertjuan untuk mendapatkan informasi dan membahas tentang penerapan model discovery learning untuk meningkatkan hasil belajar Bahasa Indonesia di kelas VIII.D SMPN 9 Muaro Jambi semester Itahun ajaran 2019/2020. Penelitian ini merupakan penelitian tindakan kelas yang terdiri dari dua siklus dimana masing-masing siklus terdiri dari dua kali pertemuan. Masing-masing siklus terdiri dari empat tahapan yaitu perencanaan, pelaksanaan, obeservasi, dan refleksi. Penelitian ini dilaksanakan di SMPN 9 Muaro Jambi dengan subjek penelitian siswa kelas VIII.D SMPN 9 MUaro Jambi yang berjumlah 26 orang pada semester ganjil tahun ajaran 2019/2020. Teknik pengumpulan data menggunakan lembar observasi, tes, catatan lapangan dan dokumentasi. Data dianalisis menggunkan persentase dan reduksi data. Hasil penelitian menunjukkan bahwa melalui model discovery learning dapat hasil belajar Bahasa Indonesia siswa di kelas VIII.D SMPN 9 Muaro Jambi semester Itahun ajaran 2019/2020 dengan tindakan memberikan reward.
\end{abstract}

Kata kunci: Hasil belajar, Bahasa Indonesia, Discovery learning

\begin{abstract}
Abtract. This research is aimed at obtaining information and discussing the application of discovery learning models to improve the results of Learning Bahasa Indonesia in grade VIII.D SMPN 9 Muaro Jambi semester I of the 2019/2020 school year. This study is a class action study consisting of two cycles in which each cycle consists of two meetings. Each cycle consists of four stages, namely planning, implementation, observation, and reflection. This research was conducted at SMPN 9 Muaro Jambi with the research subject of grade VIII.D students of SMPN 9 MUaro Jambi which amounted to 26 people in the odd semester of the 2019/2020 school year. Data collection techniques using observation sheets, tests, field records and documentation. The data is analyzed using percentages and data reduction. The results showed that through the discovery learning model can be the results of learning Bahasa Indonesia students in grade VIII.D SMPN 9 Muaro Jambi semester I of the 2019/2020 school year with the act of giving rewards.
\end{abstract}

Keywords: Learning outcomes, Bahasa Indonesia, Discovery learning

\section{PENDAHULUAN}

Pendidikan adalah hal yang esensial dalam pembentukan kepribadian dalam masyarakat yang berbudaya. Idealnya pendidikan akan melahirkan siswa yang berkarakter, bermoral, berpengetahuan dan kemampuan dasar lainnya untuk dijalankan dalam kehidupan bermasyarakat, berbangsa, dan bernegara. Undang-Undang Republik Indonesia Nomor 20 Tahun 2003 tentang Sistem Pendidikan Nasional pasal 1 ayat (1) menyatakan bahwa pendidikan adalah usaha sadar dan terencana untuk mewujudkan suasana belajar dan proses pembelajaran agar siswa secara aktif mengembangkan potensi dirinya untuk memiliki kekuatan spiritual keagamaan, pengendalian diri, kepribadian, kecerdasan, akhlak mulia, serta keterampilan yang diperlukan dirinya, masyarakat, bangsa dan negara.

Bahasa adalah belajar berkomunikasi. Di samping itu, bahasa juga merupakan penunjang keberhasilan dalam mempelajari semua bidang studi. Bahasa merupakan aspek penting dalam perkembangan intelektual, sosial, dan emosional siswa. Oleh karena itu, dalam pembelajaran Bahasa Indonesia diarahkan untuk meningkatkan kemampuan siswa dalam berkomunikasi dengan menggunakan bahasa indonesia yang baik dan benar, baik secara lisan maupun tertulis (Depdiknas, 2006:65). Pembelajaran Bahasa Indonesia meliputi aspek menyimak, berbicara, membaca, dan menulis.

Sesuai dengan kenyataan yang terjadi di lapangan tersebut, perlu adanya perbaikan yang bisa berupa peranan guru untuk melakukan perbaikan cara mengajar yang memungkinkan pesera didik terlibat secara aktif dalam belajar, sehingga hasil dapat meningkat. Salah satu metode pembelajaran yang dapat digunakan untuk meningkatkan hasil belajar siswa khususnya siswa kelas VIII.D SMPN 9 Muaro Jambi adalah discovery learning. Model ini merupakan sebuah model pembelajaran yang membantu siswa menjadi kreatif dan mandiri dalam kegiatan pembelajaran. Selain membantu siswa berkembang dan maju, metode pembelajaran discovery learning menciptakan pengalaman belajar yang tidak mudah dilupakan oleh siswa.

Belajar dalam Rahyubi (2012: 3) adalah memperoleh pengetahuan melalui pengalaman, mengingat, menguasai pengalaman, dan memperoleh atau menemukan informasi. Belajar dilakukan untuk mendapatkan perubahan dalam 
hidup melalui pengalaman. Harold Spears (Suprijono, $2009: 2$ ) mengatakan belajar adalah mengamati, membaca, meniru mencoba sesuatu, mendengar dan mengikuti arah tertentu. Hilgrad dan Bower dalam Baharuddin dan Wahyuni (2010:13) menjelaskan belajar memiliki arti memperoleh pengetahuan atau menguasai pengetahuan melalui pengalaman, mengingat, menguasai pengalaman, dan mendapatkan informasi atau menemukan. Belajar merupakan proses hidup yang dijalani manusia untuk mencapai kompetensi pengetahuan, keterampilan dan sikap. Perubahan yang didapatkan berupa perubahan pengetahuan, perubahan sikap dan perubahan keterampilan.

Beberapa pengertian yang telah dikemukakan memiliki kesamaan bahwa belajar adalah aktivitas memperoleh pengetahuan melalui pengalaman, mengingat, mendengar dan melihat yanga akan memperngaruhi pengetahuan, keteampilan dan sikap seseorang.

Hasil belajar berupa pola-pola perbuatan, nilai-nilai, pengertian, sikap, apresiasi dan keterampilan. Keefektifan belajar biasanya diukur dengan tingkat pencapaian hasil belajar. Uno (2011:21) menjelaskan "ada empat aspek penting yang digunakan utnuk mempreskripsikan keefektifan pembelajaran, yaitu kecermatan penguasan perilaku yang dipelajari atau sering disebut dengan 'tingkat kesalahan', kecapatan untuk kerja, tingkat alih belajar, dan tingkat retensi dari apa yang dipelajari." Belajar merupakan proses untuk mencapai tujuan belajar atau hasil belajar. Hasil belajar adalah kemampuan-kemampuan yang dimiliki siswa sebagai akibatperbuatan belajar dan dapat diamati melalui penampilan siswa. Setiap kegiatan belajar menghasilkan output atau outcome.

Pembelajaran menurut Gagne dalam Pribadi (2009:9) adalah serangkaian aktivitas yang sengaja diciptakan dengan maksud untuk memudahkan terjadinya proses belajar. Menurut Rusman (2012 : 134) "Pembelajaran pada hakikatnya adalah merupakan suatu proses interaksi antara guru dengan siswa, baik interaksi secara langsung seperti kegiatan tatap muka maupun secara tidak langsung, yaitu dengan menggunakan berbagai media pembelajaran.

Bahasa merupakan alat komunikasi utama dalam kehidupan umatmanusia. Pendidikan Bahasa Indonesia merupakan salah satu aspek penting yang perlu diajarkan kepada para siswa di sekolah. Permendiknas No. 22 Tahun 2006, Bahasa memiliki peran sentral dalam perkembangan intelektual, sosial, dan emosional peserta didik dan merupakan penunjang keberhasilan dalam mempelajari semua bidang studi. Pembelajaran bahasa diharapkan membantu peserta didik mengenal dirinya, budayanya, dan budaya orang lain, mengemukakan gagasan dan perasaan, berpartisipasi dalam masyarakat yang menggunakan bahasa tersebut, dan menemukan serta menggunakan kemampuan analitis dan imaginatif yang ada dalam dirinya.

Pembelajaran discovery memberi kesempatan bagi siswa untuk mengumpulkan, menyusun, memanipulasi, dan menganalisis data karena guru tidak memberi tahu siswa secara langsung, tetapi siswa menemukan konsep melalui serangkaian data atau informasi yang diperoleh melalui pengamatan atau percobaan. (Aulss and Shore, 2008 : 121). Model pembelajaran discovery menuntut guru untuk lebih kreatif menciptakan situasi yang dapat membuat siswa belajar aktif menemukan pengetahuan sendiri. Pembelajaran discovery melalui kegiatan eksperimen dapat menambah pengetahuan dan keterampilan siswa secara stimulan (Sani, 2013 : 98). Hamalik dalam Perencanaan Pengajaran Berdasarkan Pendekatan Sistem (2008 : 187), menjelaskan pendekatan discovery dapat dilakukan dalam bentuk komunikasi satu arah dan dua arah, tergantung pada besarnya kelas.

Creickshank et all dalam The Act of Teaching (2009 : 262) menjelaskan tujuan discovery learning agar siswa mencari tahu dan menemukan sendiri, siswa diharapkan tidak bergantung terlalu banyak dalam menerima pengetahuan dari guru dan menerima kesimpulan dari yang lain. Tujuan kedua discovery learning untuk membantu siswa mengetahui bagamana pengetahuan dirumuskan. Tujuan ketiga untuk meningkatkan kemampuan berpikir siswa.

Berdasarkan pengertian di atas dapat disimpulkan bahwa pembelajaran discovery learning adalah suatu model untuk mengembangkan cara belajar siswa aktif dengan menemukan sendiri, menyelidiki sendiri, maka hasil yang diperoleh akan setia dan tahan lama dalam ingatan, tidak akan mudah dilupakan siswa. Dengan belajar penemuan, anak juga bisa belajar berfikir analisis dan mencoba memecahkan sendiri problem yang dihadapi. Kebiasaan ini akan di transfer dalam kehidupan bermasyarakat.

\section{METODE PENELITIAN}

Penelitian ini merupakan penelitian tindakan kelas yang terdiri dari dua siklus dimana masing-masing siklus terdiri dari dua kali pertemuan. Masing-masing siklus terdiri dari empat tahapan yaitu perencanaan, pelaksanaan, obeservasi, dan refleksi. Penelitian ini dilaksanakan di SMPN 9 Muaro Jambi dengan subjek penelitian siswa kelas VIII.D SMPN 9 MUaro Jambi yang berjumlah 26 orang pada semester ganjil tahun ajaran 2019/2020. Teknik pengumpulan data menggunakan lembar observasi, tes, catatan lapangan dan dokumentasi. Data dianalisis menggunkan persentase dan reduksi data.

\section{HASIL PEMBAHASAN \\ Siklus I \\ Perencanaan}


Pada tahap perencanaan ini guru mempersiapkan hal-hal sebagai berikut: 1) Mempersiapkan jadwal penelitian tindakan kelas, 2) Merencanakan materi yang akan dilaksanakan pada waktu penelitianagar mengetahui kompetensi dasar yang akan disampaikan kepada siswa dalam pembelajaran, 3) Mempersiapkan silabus dan RPP, 4) Mempersiapkan rencana pembelajarandengan mengacu pada tindakan yang diterapkan dalam PTK, 5) Mempersiapkan media yang akan dipakai pada saat penelitian, 6) Mempersiapkan format Observasi, 7) Worksheet atau lembar kerja (siswa), 8) Lembar penilaian.

\section{Pelaksanaan}

Pertemuan pertama siklus I dilaksanakan pada hari Senin tanggal 29 Juli 2019 pada jam ke 6 - 7 atau pukul 11.15-12.35 WIB yang membahas tentang pengertian teks berita. Pertemuan pertama terdiri dari tiga tahapan kegiatan yaitu pendahuluan, inti dan penutup. Pada kegiatan pendahuluan ini pendidik masuk ke kelas dengan mengucapkan salam. Peserta didik menjawab salam dari pendidik. Pendidik menyapa dan menanya kabar peserta didik dengan sikap semangat. Peserta didik memberi respon yang baik kepada guru. Guru mengecek kehadian dan mengkondisikan kelas, diawali dengan berdoa bersama dipimpin oleh ketua kelas. Peserta didik mengeluarkan buku dan membaca, mencatat halaman yang dibaca. Peserta didik merespon apersepsi tentang pembelajaran pada pertemuan sebelumnya dan mengaitkannya dengan pembelajaran yang akan dipelajari, yaitu memahami resensi. Peserta didik menerima informasi tentang tujuan , manfaat, dan langkah-langkah pembelajaran memahami resensi. Untuk membangun konteks pembelajaran, peserta didik membaca dan mengamati pemahaman tentang teks berita yang ditampilkan oleh guru. Guru dan peserta didik bertanya jawab tentang pengertian resensinya baru saja ditampilkan dan pendidik mengaitkan dengan pembelajaran yang akan dielajari. Guru menugaskan siswa membaca dan memahami resensi. Peserta didik membaca dan memahami resensidengan tujuan akhir peserta didik akan bisa mengidentifikasi resensiyang sudah dibaca dan dipahami. Setelah membaca berita, pendidik memberikan latihan tentang teks yang baru saja dibaca dan dipahami. Peserta didik mengerjakan tugas yang diberikan oleh pendidik. Peserta didik bersama pendidik menyimpulkan pembelajaran. Bersama pendidik, peserta didik melakukan refleksi tentang pembelajaran yang akan dibahas pada pertemuan berikutnya. Pendidik menutup pembelajarn dengan berdoa bersama.

Pertemuan Kedua Siklus I hari jum'at tanggal 02 Agustus 2019 pada jam ke 3-4 atau pukul 08.50-10.35 WIB dengan membahas tentang unsur-unsur berita $(5 \mathrm{~W}+1 \mathrm{H})$. Pertemuan kedua ini terdiri dari tiga tahapan kegiatan yaitu pendahuluan, inti, dan penutup. Pada kegiatan pendahuluan guru memasuki kelas kelas dengan menyapa siswa dan mengucapkan salam serta mengabsen kehadiran siswa. pada peretemuan kedua ini seluruh siswa hadir. Guru menanyakan kabar siswa dan siswa member respon yang baik kepada guru. Guru mengkondisikan kelas untuk siap belajar dan memulai belajar dengan berdoa bersama yang dipimpin oleh ketua kelas. Peserta didik mengeluarkan meresposn apersepsi tentang pembelajaran pada pertemuan sebelumnya dan mengaitkannya dengan pelajaran yang akan dipelajari yaitu memahami unsur-unsur berita $(5 \mathrm{~W}+1 \mathrm{H})$.

Pada kegiatan inti ini Peserta didik membaca kembali mengenai unsur-unsur berita $(5 \mathrm{~W}+1 \mathrm{H})$ tersebut. Kemudian peserta didik mengumpulkan informasi yang relevan untuk menjawab pertanyan yang telah diidentifikasi melalui kegiatan: 1) Mengamati obyek/kejadian, mengamati dengan seksama materi yang sedang dipelajari dan mencoba menginterprestasikannya, 2) Membaca sumber lain selain buku teks, mencari dan membaca berbagai referensi dari berbagai sumber guna menambah pengetahuan dan pemahaman, 3) Aktivitas menyusun daftar pertanyaan atas hal-hal yang belum dapat dipahami dari kegiatan mengmati dan membaca yang akan diajukan kepada guru. Pada kegiatan penutup ini peserta didik bersama pendidik menyampaikan kesimpulan dari pembelajaran.Bersama pendidik, peserta melakukan refleksi tentang pembelajaran teks berita dan unsur-unsur berita $(5 \mathrm{~W}+1 \mathrm{H})$ yang sudah dilaksanakan. Peserta didik mencariinformasi tentang pembelajaran yang akan dibahas pada pertemuan berikutnya.

\section{Observasi}

Setelah dilaksanakannya proses belajar mengajar maka peneliti danobserver melakukan pengamatan terhadap hasil belajar. Pada akhirpertemuan diadakan tes untuk melihat hasil belajar matematika siswa. Hal ini dapat dilihat pada tabel berikut ini:

Tabel 1. Rekapitulasi Hasil Tes Formatif Pada Siklus I

\begin{tabular}{|c|l|c|}
\hline No. & \multicolumn{1}{|c|}{ Uraian } & Hasil Siklus I \\
\hline \hline 1. & Nilai rata-rata tes formatif & 68.31 \\
\hline 2. & Jumlah peserta didik yang tuntas belajar & 15 \\
\hline 3. & Persentase ketuntasan belajar & $57.69 \%$ \\
\hline
\end{tabular}

Dari tabel di atas dapat dijelaskan bahwa dengan menerapkan metode pembelajaran Discovery Learning diperoleh nilai rata-rata hasil belajar peserta didik adalah 68.31 dan ketuntasan belajar mencapai $57.69 \%$ atau ada 15 
peserta didik dari 26 peserta didik sudah tuntas belajar. Hasil tersebut menunjukkan bahwa pada siklus pertama secara klasikal peserta didik belum tuntas belajar, karena peserta didik yang memperoleh nilai $\geq 75$ hanya sebesar $57.69 \%$ lebih kecil dari persentase ketuntasan yang dikehendaki yaitu sebesar $80 \%$. Hal ini disebabkan karena peserta didik masih merasa baru dan belum mengerti apa yang dimaksudkan dan digunakan guru dengan menerapkan metode pembelajaran Discovery Learning.

\section{Refleksi}

Tahap refleksi dilaksanakan pada hari rabu pada tanggal 31 Juli 2019 pada pukul 09.30-11.15 WIB bertempat di ruangan kelas yang dibantu oleh seorang observer yang bernama Tuti Sumarni , S.Pd Pada siklus 1 pertemuan dua hasil belajar peserta didik sudah mulai meningkat walaupun masih berada pada kategori kurang baik. Selain itu juga ditemukan bahwa guru kurang mempersiapkan diri dengan alat-alat/ media dalam rangka melengkapi bahan yang dibutuhkan seperti laptop,infokus, buku sumber dan lainnya. Guru harus mampu membimbing siswa dalam diskusi kelompok, dan harus mendatangi semua kelompok tanpa membeda bedakannya.selalu memberikan motivasi atau semangat kepada siswa untuk selalu bersaing sehat dalam diskusi kelompok. Berdasarkan masalah di atas maka penelitian ini dilanjutkan ke siklus II dengan tindakan pemberian reward bagi kelompok yang mampu menampilkan hasil yang lebih baik dalam menjelaskan materi yang didapat. Untuk itu penelitian ini dilanjutkan ke siklus berikutya.

\section{Siklus II \\ Perencanaan}

Pada tahap ini peneliti mempersiapkan jadwal penelitian tindakan kelas, Merencanakan materi yang akan dilaksanakan pada waktu penelitian agar mengetahui kompetensi dasar yang akan disampaikan kepada siswa dalam pembelajaran, Mempersiapkan silabus dan RPP, Mempersiapkan rencana pembelajaran dengan mengacu pada tindakan yang diterapkan dalam PTK, Mempersiapkan media yang akan dipakai pada saat penelitian, Mempersiapkan format Observasi, dan mempersiapkan reward atau hadiah.

\section{Pelaksanaan}

Pertemuan pertama siklus II dilaksanakan pada hari Rabu tanggal 07 Agustus 2019 pada jam ke 4-5 atau pukul 09.30 -11.15 WIB. Pada pertemuan ini materi yang dibahas tentang ringkasan dan penyimpulan berita. Pertemuan pertama ini terdiri dari tiga tahapan yaitu kegiatan pendahuluan, inti dan penutup. Pada tahap pendahuluan ini guru mengucapkan salam dan memulai pembelajaran dengan membaca do'a. Guru memperhatikan kesiapan siswa satu persatu dari depan kelas untuk mengikuti proses pembelajaran dengan memperhatikan buku-buku dan alat tulis yang akan digunakan siswa selama proses pembelajaran di meja siswa masing-masing, sikap siswa, dan kehadiran siswa (fokus pada yang tidak hadir). Melakukan pembukaan dengan salam pembuka dan berdoa untuk memulai pembelajaran. Memeriksa kehadiran peserta didik sebagai sikap disiplin. Pada kegiatan inti Peserta didik mengumpulkan informasi yang relevan untuk menjawab pertanyan yang telah diidentifikasi melalui kegiatan: 1) Mengamati dengan seksama materi ringkasan dan penyimpulan berita yang sedang dipelajari dan mencoba menginterprestasikannya, 2) mencari dan membaca berbagai ringkasan dan penyimpulan berita dari berbagai sumber guna menambah pengetahuan dan pemahaman tentang ringkasan dan penyimpulan berita yang sedang dipelajari, 3) menyusun daftar pertanyaan atas hal-hal yang belum dapat dipahami dari kegiatan mengmati dan membaca yang akan diajukan kepada guru, 4) mengajukan pertanyaan berkaiatan dengan materi ringkasan dan penyimpulan berita yang tekah disusun dalam daftar pertanyaan kepada guru kemudian pada kegiatan inti ini Peserta didik dibentuk dalam beberapa kelompok untuk berdiskusi, Mengumpulkan informasi, Pada kegiatan penutup ini peserta didik mendiskusikan hasil pengamatannya dan memverifikasi untuk menyimpulkan hasil pengamatannya dengan data-data atau teori pada buku sumber melalui kegiatan menambah keluasan dan kedalaman sampai kepada pengolahan informasi yang bersifat mencari solusi dari berbagai sumber yang memiliki pendapat yang berbeda sampai kepada yang bertentangan. Peserta didik dan guru secara bersama-sama membahas jawaban soal-soal yang telah dikerjakan oleh peserta didik. Kemudian Menyampaikan hasil diskusi tentang materi ringkasan dan penyimpulan berita.

Pertemuan kedua siklus II dilaksanakan pada hari Jumat tanggal 09 Agustus 2019 dengan membahas materi tentang struktur teks berita; Kepala berita (lead), Tubuh berita dan Ekor berita. Pertemuan kedua siklus II terdiri dari tiga tahapan kegiatan yaitu pendahuluan, inti dan penutup. Pada kegiatan pendahuluan melakukan pembukaan dengan salam pembuka dan berdoa untuk memulai pembelajaran. Memeriksa kehadiran peserta didik sebagai sikap disiplin. Menyiapkan fisik dan psikis peserta didik dalam mengawali kegiatan pembelajaran. Mengaitkan materi/tema/kegiatan pembelajaran yang akan dilakukan dengan pengalaman peserta didik dengan materi/tema/kegiatan sebelumnya. Mengingatkan kembali materi prasyarat dengan bertanya. Mengajukan pertanyaan yang ada keterkaitannya dengan pelajaran yang akan dilakukan. Peserta didik mengumpulkan informasi yang relevan untuk menjawab pertanyan yang telah diidentifikasi melalui kegiatan: 1) Mengamati obyek/kejadian, mengamati dengan seksama materi Struktur teks 
berita; Kepala berita (lead), Tubuh berita dan Ekor beritayang sedang dipelajari dan mencoba menginterprestasikannya, 2) Membaca sumber lain selain buku teks, mencari dan membaca berbagai struktur teks berita; Kepala berita (lead), Tubuh berita dan Ekor beritadari berbagai sumber guna menambah pengetahuan dan pemahaman tentang materi Struktur teks berita; Kepala berita (lead), Tubuh berita dan Ekor beritayang sedang dipelajari, 3) Aktivitas, menyusun daftar pertanyaan atas hal-hal yang belum dapat dipahami dari kegiatan mengmati dan membaca yang akan diajukan kepada guru. Wawancara/tanya jawab dengan narasumber, mengajukan pertanyaan berkaiatan dengan materi struktur teks berita; Kepala berita (lead), Tubuh berita dan Ekor beritayang tekah disusun dalam daftar pertanyaan kepada guru. Pada kegiatan penutup peserta didik bersama pendidik Peserta didik mendiskusikan hasil pengamatannya dan memverifikasi untuk menyimpulkan hasil pengamatannya dengan data-data atau teori pada buku sumber melalui kegiatan Menambah keluasan dan kedalaman sampai kepada pengolahan informasi yang bersifat mencari solusi dari berbagai sumber yang memiliki pendapat yang berbeda sampai kepada yang bertentangan. Peserta didik dan guru secara bersama-sama membahas jawaban soal-soal yang telah dikerjakan oleh peserta didik.Menyampaikan hasil diskusi tentang materi struktur teks berita; Kepala berita (lead), Tubuh berita dan Ekor beritaberupa kesimpulan. Mempresentasikan hasil diskusi kelompok secara klasikal tentang materi struktur teks berita; Kepala berita (lead), Tubuh berita dan Ekor berita. Kemudian Mengemukakan pendapat atas presentasi yang dilakukan tentanag materi merekonstruksi resensidan ditanggapi oleh kelompok yang mempresentasikan. Bertanya atas presentasi tentang materi struktur teks berita; Kepala berita (lead), Tubuh berita dan Ekor beritayang dilakukan dan peserta didik lain diberi kesempatan untuk menjawabnya. Menyimpulkan tentang point-point penting yang muncul dalam kegiatan pembelajaran. Menjawab pertanyaan tentang struktur teks berita; Kepala berita (lead), Tubuh berita dan Ekor beritayang terdapat pada buku pegangan atau lembar kerja yang telah disediakan. Bertanya tentang hal yang belum dipahami, atau guru melemparkan beberapa pertanyaan berkaitan dengan materi struktur teks berita; Kepala berita (lead), Tubuh berita dan Ekor berita.

\section{Observasi}

Pengamatan (observasi) dilaksanakan bersamaan dengan pelaksanaan belajar mengajar. Berikutnya adalah rekapitulasi hasil tes formatif peserta didik terlihat pada tabel berikut.

Tabel 2. Rekapitulasi Hasil Tes Formatif Pada Siklus II

\begin{tabular}{|c|l|c|}
\hline No. & \multicolumn{1}{|c|}{ Uraian } & Hasil Siklus II \\
\hline \hline 1. & Nilai rata-rata tes formatif & 82.5 \\
\hline 2. & Jumlah peserta didik yang tuntas belajar & 22 \\
\hline 3. & Persentase ketuntasan belajar & $84.62 \%$ \\
\hline
\end{tabular}

Dari tabel di atas diperoleh nilai rata-rata hasil belajar peserta didik adalah 82.5 dan ketuntasan belajar mencapai $84.62 \%$ atau ada 22 peserta didik dari 26 peserta didik sudah tuntas belajar. Hasil ini menunjukkan bahwa pada siklus II ini ketuntasan belajar secara klasikal telah mengalami peningkatan lebih baik dari siklus I.

\section{Refleksi}

Tahap refleksi siklus II dilaksanakan pada hari Jumat tanggal 09 Agustus 2019 pada jam ke 6-7 Jam 11.15 sampai 12.35 Wib dengan dibantu oleh seorang observer yang bernama Tuti marwiyah, S.Pd yang bertempat di ruangan majelis guru. Dalan didkusi ini guru dan observer menjelaskan bahwa adanya peningkatan hasil belajar peserta didik ini karena setelah guru menginformasikan bahwa setiap akhir pelajaran akan selalu diadakan tes sehingga pada pertemuan berikutnya peserta didik lebih termotivasi untuk belajar. Selain itu peserta didik juga sudah mulai mengerti apa yang dimaksudkan dan dinginkan guru dengan menerapkan metode pembelajaran Discovery Learning.Hasil yang didapat ketuntasan siswa sebesar $84.62 \%$ atau 22 orang siswa dari 26 siswa sudah tuntas belajar. Hal ini dapat disimpulkan bahwa pada siklus II ini hasil belajar siswa sudah mencapai target yang diharapkan dan ketuntasan juga meningkat dengan menerapakan model pembelajaran discovery learning. Oleh karena itu penelitian ini tidak dilanjutkan ke siklus berikutya.

\section{Pembahasan}

Melalui hasil peneilitian ini menunjukkan bahwa metode pembelajaran Discovery Learning memiliki dampak positif dalam meningkatkan hasil belajar peserta didik. Hal ini dapat dilihat dari semakin mantapnya pemahaman peserta didik terhadap materi yang disampaikan guru (ketuntasan belajar meningkat dari siklus I, dan II yaitu masingmasing $57.69 \%$, dan $84.62 \%$. Pada siklus II ketuntasan belajar peserta didik secara klasikal telah tercapai.

Dalam pembelajaran dengan model pembelajaran Discovery Learning ini siswa diarahkan menemukan konsep dengan bantuan membaca buku melalui kegiatan-kegiatan diskusi. Dalam pembelajaran, guru membimbing siswa berada disamping mereka yang membutuhkan bimbingan, membuat siswa merasa puas dan senang dan merasa 
diperhatikan sehingga siswa merasa bersemangat belajar. Pelaksanaan model discovery learning di kelas VIII.D SMPN 9 Muaro Jambi telah memberikan dampak yang positif.

Hosnan (2014: 7) menyatakan bahwa belajar pada hakikatnya adalah proses interaksi terhadap semua yang ada di sekitar individu. Melaksanakan pengelolaan kelas dengan baik agar siswa termotivasi dalam mengikuti pembelajaran serta Memberikan pujian kepada siswa dapat meningkatkan hasil belajarnya karena termotivasi dalam pembelajaran. Hal ini sesuai dengan pendapat Sudjana (2004) bahwa hasil belajar siswa pada hakikatnya adalah perubahan tingkah laku sebagai hasil belajar dalam pengertian yang lebih luas mencakup bidang kognitif, afektif, dan psikomotorik.

\section{SIMPULAN}

Dari hasil kegiatan pembelajaran yang telah dilakukan selama dua siklus, dan berdasarkan seluruh pembahasan serta analisis yang telah dilakukan dapat disimpulkan bahwa melalui model pembelajarn discovery learning dapat meningkatkan hasil belajar Bahasa Indonesia siswa kelas VIII.D SMPN 9 Muaro Jambi, hal ini ditandai dengan peningkatan hasil belajar siswa dari siklus ke siklus dengan tindakan pemberian reward atau hadiah.

\section{DAFTAR PUSTAKA}

Agus Suprijono. 2009. Cooperative Learning: Teori dan Aplikasi PAIKEM. Yogyakarta: Pustaka Pelajar Arikunto dkk.Penelitian Tindakan Kelas. 2012. Jakarta: Bumi Aksara.

Aulls, M.W., \& Shore, B.M. 2008. Inquiry in Education: The Conceptual Foundations for Research as a Curricular Imperative. New York: Lawrance Erlbaum Associates.

Baharuddin. Esa Nur Wahyuni. 2010. Teori Belajar dan Pembelajaran. Yogyakarta: Ar-Ruzz Media.

Creickshank, Donald et all. The Act of Teaching. 2009. Pennsylvania State University: McGraw-Hill.

Hamalik, Oemar. 2012. Kurikulum dan Pembelajaran. Jakarta: Bumi Aksara.

Hamalik, Oemar. 2008. Perencanaan Pengajaran Berdasarkan Pendekatan Sistem. Jakarta: Bumi Aksara.

Hosnan. 2014. Pendekatan Saintifik dan Kontekstual dalam Pembelajaran Abad 21. Bogor: Ghalia Indonesia.

Kunandar. 2011. Penelitian Tindakan Kelas. Jakarta: Rajawali Pers

Roestiyah. 2008. Strategi Belajar Mengajar. 2008. Jakarta: Rineka Cipta

Pribadi, Benny. 2009. Model Desain Sistem Pembelajaran. Jakarta: PT Dian. Rakyat

Rahyubi, Heri. 2012. Teori-Teori Belajar dan Aplikasi Pembelajaran Motorik: Deskripsi dan Tinjauan Kritis. Bandung: Nusa Media.

Rusman. 2012. Model-Model Pembelajaran. Jakarta : Rajawali Press.

Sani, Ridwan Abdullah. 2013. Inovasi Pembelajaran.Jakarta : Bumi Aksara.

Suprijono Agus. 2012. Cooperative Learning.. Yogyakarta: Pustaka Pelajar.

Undang-Undang Republik Indonesia Nomor 20 Tahun 2003 tentang Sistem Pendidikan Nasional pasal 1 ayat (1)

Uno,Hamzah B. 2011. Perencanaan Pembelajaran. Jakarta : Bumi Aksara. 